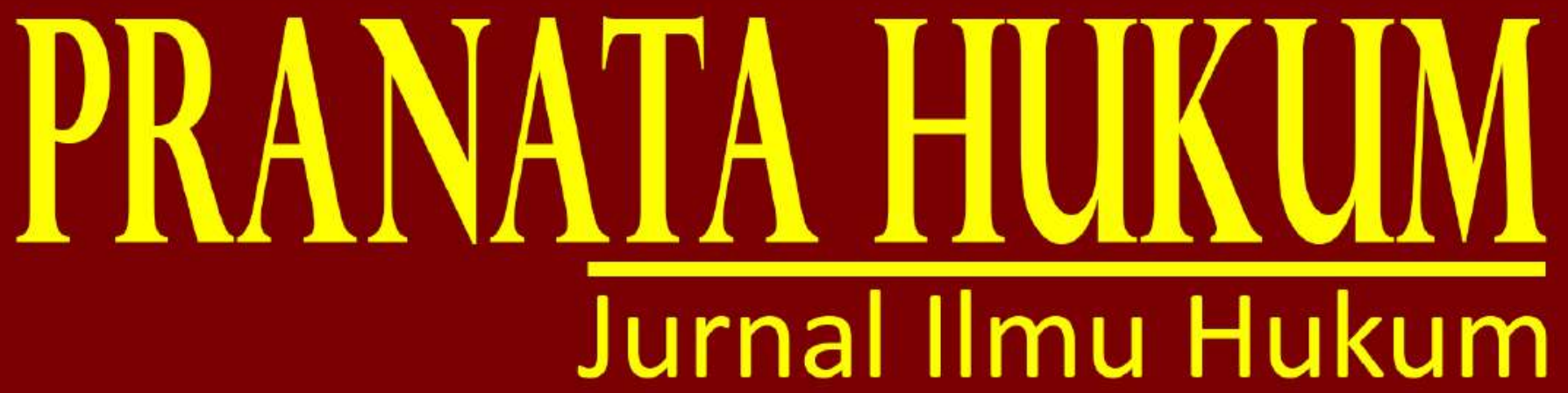

e-ISSN 2685-3213 | p-ISSN 1907-560X

SINERGITAS PEMERINTAHAN DESA DALAM PEMBENTUKAN PERATURAN DESA Anggalana

PENYELESAIAN SENGKETA PERBANKAN BERKAITAN DENGAN PERLINDUNGAN KONSUMEN Dian Herlambang, Muhammad Ridho Wijaya

ANALISIS KOMPARASI ANTARA PERLINDUNGAN PATEN BIASA DENGAN PATEN SEDERHANA BERDASARKAN UNDANG-UNDANG PATEN

Erlina, Melisa Safitri

KONSEPSI NEGARA HUKUM PANCASILA DAN IMPLEMENTASINYA DI INDONESIA Tubagus Muhammad Nasarudin

ANALISIS KEBIJAKAN PEMUNGUTAN RETRIBUSI PELAYANAN PERSAMPAHAN KEBERSIHAN DALAM RANGKA PENINGKATAN PENDAPATAN ASLI DAERAH DI KOTA BANDAR LAMPUNG Pertiwi Agustina RA, Lintje Anna Marpaung, Herlina Ratna Sumbawa Ningrum

ANALISIS KEDUDUKAN PERATURAN DESA PASCA PENGESAHAN UNDANG-UNDANG NOMOR 6 TAHUN 2014 TENTANG DESA DI DESA BADRAN SARI DAN NAMBAH REJO KABUPATEN LAMPUNG TENGAH

Baharudin, Indah Satria, Ramanda Ansori

FANATISME DAN EKSISTENSI NILAI-NILAI DEMOKRASI KADER NAHDLATUL ULAMA KOTA METRO PADA PILPRES 2019

Hendra Irawan, Ika Selviana

PERLINDUNGAN HUKUM TERHADAP PEMENANG LELANG BARANG RAMPASAN NEGARA BERUPA KENDARAAN RODA DUA YANG DIEKSEKUSI DENGAN CARA LELANG OLEH KEJAKSAAN

Okta Vianus Puspa Negara, Zainab Ompu Jainah, S. Tri Herlianto

ANALISIS PERTANGGUNGJAWABAN PELAKU TINDAK PIDANA MENGGANDAKAN SURAT PALSU UNTUK BEKERJA DI PT. GREAT GIANT PINEAPPLE HUMAS JAYA

Helmi Rangkuti, Ketut Seregig, Tami Rusli

MAGISTER HUKUM

UNIVERSITAS BANDAR LAMPUNG

\begin{tabular}{c|c|c|c|l}
$\begin{array}{c}\text { PRANATA } \\
\text { HUKUM }\end{array}$ & $\begin{array}{c}\text { Volume } \\
15\end{array}$ & $\begin{array}{c}\text { Nomor } \\
1\end{array}$ & $\begin{array}{c}\text { Halaman } \\
1-119\end{array}$ & $\begin{array}{l}\text { Bandar } \\
\text { Lampung } \\
\text { Januari } 2020\end{array}$ \\
\hline
\end{tabular}




\section{PRANATA HUKUM}

Jurnal Ilmu Hukum

Magister Hukum

Universitas Bandar Lampung

Terbit Pertama Kali, Juli 2006

Terbit Dua Kali Setahun, Setiap Januari dan Juli

EDITOR IN-CHIEF

Prof. Dr. Lintje Anna Marpaung, S.H., M.H

EDITORIAL BOARDS MEMBERS

Dr. Bambang Hartono, S.H., M.Hum

Dr. Tami Rusli, S.H., M.Hum

Dr. Erlina B, S.H., M.H

Dr. Zainab Ompu Jainah, S.H., M.H

Dr. Zulfi Diane Zaini, S.H., M.H

MANAGING EDITOR

Indah Satria, S.H., M.H

ASSISTANT EDITORS

Yulia Hesti, S.H., MH

Shany Carolina Mawuntu

\section{PENYUNTING AHLI (MITRA BESTARI)}

Prof. Dr. I Gusti Ayu Ketut Rachmi Handayani, S.H., M.M (Universitas Sebelas Maret)

Prof. Dr. I Gede A.B Wiranata, S.H., M.H (Universitas Lampung)

Dr. Nurhadiantomo, S.H., M.Hum (Universitas Muhammdiyah Surakarta)

Dr. Erina Pane, S.H., M.H (UIN Lampung)

\section{Alamat: \\ Kampus B Universitas Bandar Lampung}

Jl. Z.A Pagar Alam No.89 Labuhan Ratu, Bandar Lampung 35142

Telp: 0721-789825 Fax: 0721-770261

Email: jurnal.mh@ubl.ac.id

Jurnal PRANATA HUKUM dimaksudkan sebagai media komunikasi ,edukasi dan informasi ilmiah bidang ilmu hukum. Sajian dan kemasan diupayakan komunikatif melalui bahasa ilmiah.

Redaksi mengundang semua elemen masyarakat ,baik civitas akademika, praktisi , lembaga masyarakat, maupun perorangan yang berminat terhadap bidang hukum untuk berpartisipasi mengembangkan gagasan, wawasan, dan pengetahuan melalui tulisan untuk dimuat dalam jurnal ini. Melalui PRANATA HUKUM diharapkan terjadi proses pengembangan bidang hukum sebagai bagian penting dari rangkaian panjang proses memajukan masyarakat bangsa 


\title{
ANALISIS KOMPARASI ANTARA PERLINDUNGAN PATEN BIASA DENGAN PATEN SEDERHANA BERDASARKAN UNDANG-UNDANG PATEN
}

\author{
Erlina, ${ }^{1}$ Melisa Safitri ${ }^{2}$
}

\begin{abstract}
This journal discusses the comparison of legal protections against ordinary patents with simple patents in the patent legal system in Indonesia. The method of normative juridical research is descriptive with a statutory approach supported by a theoretical approach, namely by studying and reviewing the provisions of Law No. 13 of 2016 on patents with legal theory to know the comparison of legal protections against ordinary patents and simple patents in the patent legal system in Indonesia.
\end{abstract}

\section{Keywords: patent, simple patent, legal protection comparison}

\section{PENDAHULUAN}

Kemajuan teknologi informasi dan transportasi yang sangat pesat dalam era globaliasi ini mengakibatkan perlindungan sebuah merek dagang serta paten sangat penting.Hak kebendaan terdiri dari atas hak benda materil dan hak benda immateril. Mengenai HKI termasuk hakbenda yang tidak berwujud atau immaterial, yang secara garis besar HKI dibagi dalam 2(dua) bagian yaitu hak cipta (copyrights) dan hak kekayaan industri (industrial propertyrights) yang mencakup paten (patent), desain insdustri (industrial design), merek (trademark), penanggulangan praktek persaingan curang (repression of unfair competition),desain tata letak sirkuit terpadu (layout design of integrated circuit), dan rahasia dagang(tradesecret).$^{3}$

Khusus mengenai paten, maka suatu "paten" diberikan terhadap karya atau ide penemuan (invensi) di bidang teknologi, yang setelah diolah dapat menghasilkan suatuproduk maupun hanya merupakan proses saja. ${ }^{4}$.

\footnotetext{
${ }^{1}$ Dosen Fakultas Hukum Universitas Bandar Lampung, erlina@ubl.ac.id

2 Dosen Fakultas Hukum Universitas Bandar Lampung, melisa.safitri@ubl.ac.id

3 Monika Suhayati., Perlindungan Hukum Terhadap Hak Ekonomi Pemilik Hak Terkait Dalam Undang-Undang Nomor : 28 Tahun 2014 Tentang Hak Cipta. Jurnal Ilmiah Hukum Negara Hukum (Membangun Hukum Untuk Keadilan danKesejahteraan) Volume 5 Nomor : 2 Nopember 2014. Pusat Kajian, Pengolahan Data dan Informasi (P3DI) Sekretariat Jenderal Dewan Perwakilan Rakyat Republik Indonesia. hlm. 14.

4 Rachmadi Usman. 2003. Hukum Hak atas Kekayaan Intelektual Perlindungan dan DimensiHukumnya di Indonesia. Alumni, Bandung. hlm.207
} 
Teknologimerupakan suatu bidang yang berkaitan erat dengan hak atas kekayaancendekiawi khususnya dengan paten dan merek. ${ }^{5}$

Sejarah telah mencatat bahwa banyak sekali bisnis yang tumbuh besar dan meraup keuntungan yang sangat besar karena mampu memanfaatkan kekuatan merek dan paten mereka.Sebut perusahaan Apple dan Samsung yang memiliki puluhan bahkan ratusan paten sehingga mereka dapat menciptakan produkproduk yang revolusioner dan menjadi perusaahaan teknologi terkemuka di dunia.Apple dan Samsung sama-sama mampu melindungi hasil penemuanpenemuan mereka dengan Paten, dan bahkan tak tanggung-tanggung, mereka menempuh berbagai jalur hukum untuk melindungi Paten mereka seperti sengketa Apple dan Samsung terkait fungsi untuk koreksi ejaan otomatis Perangkat Apple.

Selain persoalan objek paten yang diatur dalam Undang-undang lama dengan Undang-Undang paten yang baru, berbagai macam perbedaan pengaturan dalam perlindungan hukum antara paten biasa dan paten sederhana menjadi menarik untuk di bahas sehingga memudahkan pembaca dalam hal ini masyarakat luas untuk lebih memahami permasalahan hukum dalam bidang industri hak kekayaan intelektual khususnya dalam konteks hukum paten di indonesia. Metode pendekatan yang digunakan penulis adalah yuridis normatif, yaitu menggambarkan kepada pihak lain tentang apa dan bagaimana korelasi hukum positif dengan materi penelitian. Data Primer bersumber dari perundang-undangan, jurnal, laporan penelitian, internet, buku-buku yang berkaitan dengan pembahasan tesis ini dan data sekunder bersumber dari dokumen-dokumen yang berkaitan dengan perlindungan hukum terhadap paten biasa dan paten sederhana dalam sistem hukum paten di Indonesia.

\section{PEMBAHASAN}

Seorang peneliti dalam suatu penelitian hampir selalu menggunakan beberapa teori.Menurut Popper teori adalah ciptaan manusia. Teori hanyalah pendugaan dan pengiraanyang berarti teori tidak pernah benar mutlak. Ilmu baru dapat berkembang jika tiap-tiapteori secara terus-menerus diuji kebenarannya. Cara pengujiannya adalah denganmenunjukkan kesalahan dari teori itu, bukan sebaliknya. ${ }^{6}$ Sementara itu John Locke dalam teorinya tentang hak milik mengatakan bahwa hakmilik dari seorang manusia terhadap benda yang dihasilkannya itu sudah ada sejak manusiaitu lahir. John Locke mengemukakan bahwa hukum hak kekayaan intelektual memberikanhak milik eksklusif kepada

50entoeng Soerapati. 1999. Hukum Kekayaan Intelektual dan Alih Teknologi. Satya Wacana, Salatiga Hlm. 97.

${ }^{6}$ Shidarta. 2009.Misnomer dalam Nomenklatur dan Penalaran Positivisme Hukum. Yayasan Obor Indonesia, Jakarta. hlm. 59. 
hasil karya seseorang. ${ }^{7}$ Kemudian Lockemenyatakan bahwa hak atas milik pribadi bermula dari kerja manusia dan dengan kerjainilah manusia memperbaiki dunia demi kehidupan yang layak, baik untuk dirinya sendirimaupun orang lain. Asumsi ini mengantar Locke pada suatu pemikiran bahwa kerjaindividu juga menjadi milik individu. ${ }^{8}$ Sedangkan barangadalah benda materil (berwujud) dan hak merupakan benda immateril (tidak berwujud).

Dalam sejarah perkembangan hukum di Indonesia khususnya di bidang hukum privat atau hukum perdata, terdapat pengaturan mengenai hak kebendaan. Menurut Pasal 499 KUH Perdata benda adalah tiap-tiap barang dan tiap-tiap hak yang dapat dikuasai olehhak milik. Mahadi kemudian menawarkan seandainya dikehendaki rumusan lain daripasal ini dapat diturunkan kalimat berikut; yang dapat menjadi obyek hak milik adalahbenda dan benda itu terdiri dari barang dan hak. ${ }^{9}$ Berdasarkan pengertian tersebut, dapat disimpulkan bahwa pengertian benda merupakan setiap barangdan hak yang dapat dikuasai oleh seseorang sebagai hak milik. Selanjutnya sebagaimana diterangkan oleh Mahadi barang yang dimaksudkan oleh pasal 499 KUH Perdata tersebut adalah benda materil, sedangkan hak adalah benda immateril. Uraian ini sejalandengan klasifikasi benda menurut pasal 503 KUH Perdata (Begerlijk wet Book) yaitupenggolongan benda ke dalam kelompok benda berwujud dan benda tidak berwujud. Karena hak kebendaan diatur dalam KUH Perdata atau Begerlijk wet Book (BW),maka perlu dipahami bahwa BW terdiri dari 4 (empat) buku yaitu (i) Buku I mengatur tentang Hukum Kekeluargaan (ii) Buku II mengatur tentang Hukum Kebendaan ${ }^{10}$ (iii) Buku III mengatur tentang Hukum Perikatan dan (iv) Buku IVmengatur tentang Hukum Kepailitan dan Kadaluarsa. Berkenaan dengan HukumKebendaan sebagaimana yang diatur dalam Buku II, khususnya yang mengatur tentanghak-hak atas kebendaan hanya dikenal atas hak kebendaan yang berwujud (tangible object)dalam bahasa Belanda disebut dengan istilah "lichamelijk zaak" dan belum mengenal atashak kebendaan yang tidak berwujud (intangible object) dalam bahasa Belanda disebutdengan istilah "onlichamelijk zaak".

7 John Locke. 1997. Summa Theologiaedalam Sonny Keraf, Hukum Kodrat dan Teori HakMilik Pribadi. Kanisius, Yogyakarta, hlm. 77.

${ }^{8}$ Marshall Leaffer. 2007. Understanding Copyright Law. Oxford Legal Publisher, Kanada, hlm. 20.

9 Mahadi. 1981. Hak Milik dalam sistem Hukum Perdata Nasional. BPHN, Jakarta. hlm. 65.

10 Titik Triwulan Tutik. 2008. Hukum Perdata dalam Sistem Hukum Nasional. Kencana, Jakarta. hlm. 45. 


\section{A. Perlindungan hukum paten biasa dan paten sederhana dalam sistem hukum di Indonesia}

Terdapat 2 jenis paten yaitu paten biasa dan paten sederhana. Paten biasa adalah paten yang melalui penelitian atau pengembangan yang mendalam dengan lebih dari satu klaim. Paten sederhana adalah paten yang tidak membutuhkan penelitian atau pengembangan yang mendalam dan hanya memuat satu klaim. Namun, secara tersirat terdapat jenis-jenis paten yang lain, yaitu paten proses dan paten produk. Paten proses adalah paten yang diberikan terhadap proses, sedangkan paten produk adalah paten yang diberikan terhadap produk. Subjek paten, yaitu : "Inventor adalah seorang yang secara sendiri atau beberapa orang yang secara bersama-sama melaksanakan ide yang dituangkan ke dalam kegiatan yang menghasilkan Invensi." Mengenai subjek paten, bahwa yang berhak memperoleh paten adalah inventor atau yang menerima lebih lanjut hak inventor yang bersangkutan,Jika suatu invensi dihasilkan oleh beberapa orang secara bersama-sama, hak atas invensi tersebut dimiliki secara bersama-sama oleh para inventor yang bersangkutan.

Kedudukan Inventor adalah sama dengan pemegang paten. Namun hal tersebut tidaklah selalu terjadi di dalam praktik. Ada kalanya Inventor dan pemegang paten tidak berada dalam tangan yang sama. Inventor tidak selalu memiliki kemampuan untuk memproduksi Invensi. Oleh karena itu, Inventor biasanya menjual Invensinya tersebut (assignment) kepada pihak investor yang selanjutnya menjadi pemegang paten. Nama Inventor sebagai pihak yang menghasilkan Invensi itu tetaplah dicantumkan dalam sertifikat paten. Pencantuman nama tersebut merupakan perwujudan dari hak moral, yaitu hak yang melekat dalam diri si Inventor walaupun kepemilikan atas Invesinya telah beralih kepada pihak lain.

Dalam kasus penjualan hak paten, pelaksanaan hak eksklusif yang dilaksanakan oleh pemegang paten, bukan Inventor. Yang berhak memperoleh paten adalah Inventor atau yang menerima lebih lanjut hak Inventor tersebut. Ketentuan ini memberi penegasan bahwa hanya penemu atau yang berhak menerima lebih lanjut hak penemu, misalnya karena pewarisan, hibah, wasiat, perjanjian, atau sebab-sebab lain, yang berhak memperoleh paten atas penemuan yang bersangkutan. Yang dianggap sebagai penemu adalah mereka yang untuk pertama kali mengajukan permintaan paten, kecuali terbukti sebaliknya. Artinya undang-undang memakai titik tolak bahwa orang atau badan yang pertama kali mengajukan permintaan paten dianggap sebagai penemunya. Tetapi apabila di kemudian hari terbukti sebaliknya dengan bukti kuat dan meyakinkan, maka status sebagai penemu dapat berubah. 


\section{B. Perlindungan Hak Paten di Indonesia}

1) Perlindungan Hak Paten Biasa di Indonesia

Suatu paten yang telah habis masa berlakunya tidak dapat diperpanjang lagi sesuai dengan Pasal22 Undang-Undang Nomor 13 Tahun 2016 tentang Paten ("UU Paten") sebagai berikut :

1. Paten diberikan untuk jangka waktu 20 (dua puluh) tahun terhitung sejak Tanggal Penerimaan.

2. Jangka waktu sebagaimana dimaksud pada ayat (1) tidak dapat diperpanjang.

3. Tanggal mulai dan berakhirnya jangka waktu Paten dicatat dan diumumkan melalui media elektronik dan/atau media non-elektronik.

Jika masa perlindungan hak paten telah berakhir, maka suatu invensi akan menjadi public domain (milik umum) sehingga pihak lain dapat memproduksi dan menjualnya secara bebas. Aturan mengenai masa berlaku hak paten dimaksudkan agar tidak ada pihak yang secara terus menerus dapat mengontrol seluruh industri sehingga dikhawatirkan dapat merugikan masyarakat dan sistem perdagangan.Hak paten berlaku teritorial. Secara umum, hak eksklusif ini hanya berlaku di negara atau wilayah di mana paten telah diajukan dan diberikan, sesuai dengan hukum negara atau wilayah yang bersangkutan.

Paris Convention for the Protection of Industrial Property menerapkan prinsip 'national treatment' sebagaimana tertuang dalam Pasal 2 ayat (1) sebagai berikut : Nationals of any country of the Union shall, as regards the protection of industrial property, enjoy in all the other countries of the Union the advantages that their respective laws now grant, or may hereafter grant, to nationals; all without prejudice to the rights specially provided for by this Convention. Consequently, they shall have the same protection as the latter, and the same legal remedy against any infringement of their rights, provided that the conditions and formalities imposed upon nationals are complied with.

Adanya prinsip 'national treatment' ini berarti bahwa:

1. Bangsa dari negara anggota Union memiliki hak yang sama dalam perlindungan HKI;

2. Agar mendapatkan hak yang sama, pemohon harus memenuhi persyaratan yang berlaku sesuai undang-undang negara setempat.

Selanjutnya, Pasal 19 ayat (1) huruf a UU Paten menyatakan bahwa Pemegang Paten memiliki hak eksklusif untuk melaksanakan Paten yang dimilikinya dan melarang pihak lain yang tanpa persetujuannya dalam hal Patenproduk: membuat, menggunakan, menjual, mengimpor, menyewakan, menyerahkan, atau menyediakan untuk dijual atau disewakan atau diserahkan produk yang diberi Paten. Sedangkan dalam Pasal 1 angka 6 UU Paten yang dimaksud dengan pemegang paten adalah inventor sebagai pemilik paten atau 
pihak yang menerima hak tersebut dari pemilik paten atau pihak lain yang menerima lebih lanjut hak tersebut, yang terdaftar dalam daftar umum paten.

Jadi, apakah boleh membuat suatu alat untuk kepentingan komersial dimana alat tersebut telah didaftarkan patennya oleh pihak lain di negara lain, akan tetapi di Indonesia tidak didaftarkan, pada dasarnya memang tidak ada aturan hukum yang mengatur mengenai larangan untuk melakukan hal tersebut karena berlakunya aturan hukum paten yang bersifat teritorial.

Akan tetapi tindakan memproduksi suatu alat yang telah terdaftar hak patennya meski di negara lain tanpa seizin pemegang hak patennya adalah tindakan yang melanggar moral. Kekayaan Intelektual ("KI") bukan hanya mencakup perlindungan hukum, akan tetapi juga merupakan penghargaan kepada hasil karya intelektual seseorang. Hasil pemikiran manusia adalah sumber kekayaan dan kelangsungan hidup dan bahwa semua properti pada dasarnya adalah KI.

Melanggar KI seseorang sama halnya dengan secara moral melanggar KI yang terkait dengan proses-proses kehidupan dan karena itu merupakan tindakan tidak bermoral. Selain paten, terdapat juga paten sederhana. Pasal 1 angka 1 UU Paten menyatakan sebagai berikut: Paten adalah hak eksklusif yang diberikan oleh negara kepada inventor atas hasil invensinya di bidang teknologi untuk jangka waktu tertentu melaksanakan sendiri invensi tersebut atau memberikan persetujuan kepada pihak lain untuk melaksanakannya.

Untuk membedakan antara paten dengan paten sederhana, terlebih dahulu kita harus membahas mengenai apa yang dimaksud dengan invensi. Pasal 1 angka 2 UU Paten menyatakan yang dimaksud dengan invensi adalah ide inventor yang dituangkan ke dalam suatu kegiatan pemecahan masalah yang spesifik di bidang teknologi berupa produk atau proses atau penyempurnaan dan pengembangan produk atau proses.

2) Perlindungan Hak Paten Sederhana di Indonesia

Di Indonesia, jangka waktu paten dihitung mulai tanggal pemberian paten atau mulai tanggal pengumuman paten itu. Salah satu pertimbangan untuk pemberian hak atas paten adalah untuk memberi imbalan kepada si penemu atas usaha dan investasi yang telah ditanamkan dalam penemuannya itu, maka jangka waktu berlakunya paten itu penting karena masa itu si pemegang paten dapat memanfaatkan hak khususnya dengan cara memberikan lisensi (licence) atau izin khusus kepada seseorang atau badan hukum, bahwa pihak yang diberi izin itu boleh membuat barang, cara kerja atau melakukan perbuatan-perbuatan mengenai pendapat si pemegang yang sudah dipatenkan, sedangkan bagi pihak lain yang tidak diberi izin tidak diperkenankan untuk melakukan hal yang sama. Ia hanya dapat melakukan hal yang sama bila paten itu menjadi public domain (milik masyarakat), setelah jangka waktu paten itu berakhir. Sayangnya setelah 
masa 20 tahun invensi itu sering menjadi tertinggal. Bahkan tidak hanya 20 tahun, 5 tahun saja invensi baru sudah ditemukan untuk jenis produk (atau proses) yang sama.

Adapun syarat-syarat administratif yang harus dipenuhi untuk mengajukan permintaan paten dapat dilihat dalam Pasal 24 Undang-Undang Nomor 13 Tahun 2016 yang berbunyi sebagai berikut :

1. Permohonan diajukan secara tertulis dalam bahasa Indonesia kepada Direktorat Jenderal.

Permohonan harus memuat :

a. tanggal, bulan, dan tahun permohonan;

b. alamat lengkap dan alamat jelas pemohon;

c. nama lengkap dan kewarganegaraan inventor;

d. nama dan alamat lengkap kuasa apabila permohonan diajukan melalui kuasa;

e. surat kuasa khusus, dalam hal permohonan diajukan oleh kuasa;

f. pernyataan permohonan untuk dapat diberi paten;

g. judul invensi;

h. klaim yang terkandung dalam invensi;

i. deskripsi tentang invensi yang secara lengkap memuat keterangan tentang cara melaksanakan invensi;

j. gambar yang disebutkan dalam deskripsi yang diperlukan untuk memperjelas invensi, dan

k. abstraksi invensi.

2. Ketentuan lebih lanjut tentang tata cara pengajuan permohonan diatur dengan Peraturan Pemerintah.

Prinsip ideal perlindungan paten adalah sama dengan perlindungan HKI lainnya sepanjang kesemuanya bermaksud untuk melindungi seseorang yang menemukan hal sesuatu agar supaya buah pikiran dan pekerjaannya tidak dipergunakan begitu saja oleh orang lain dan menikmati hasilnya dengan merupakan hasil jerih payah mereka yang telah bekerja keras, berpikir dan mengeluarkan biaya untuk mendapatkannya. Jika dibandingkan antara hak cipta dengan paten, perbedaan antara keduanya adalah wujud hak cipta oleh hukum dalam prinsipnya diakui sejak saat semula, dan hukum hanya mengatur dalam hal perlindungannya.

Pemeriksaan kedua yaitu mengenai substansinya mencakup pemeriksaan terhadap kebaruan suatu penemuan, 
ada atau tidaknya langkah inventif, serta dapat atau tidaknya penemuan tersebut diterapkan dalam industri. Persyaratan substantif :

a. Suatu penemuan dapat diberikan Paten apabila merupakan hasil penemuan baru dalam bidang teknologi, dengan kata lain harus merupakan hal yang baru (new), penemuan itu merupakan penemuan baru yang memiliki kebaruan atau Novelty, syarat kebaruan atau novelty ini merupakan syarat mutlak. Suatu penemuan dapat dikatakan baru jika penemuan tersebut tidak diantisipasi oleh prior art. Persyaratan substantif yang kedua adalah persyaratan langkah inventif (inventife steps). Suatu penemuan dikatakan mengandung langkah inventif, jika penemuantersebut bagi seorang yang mempunyai keahlian tertentu dibidang tehnik merupakan hal yang tidak dapat diduga sebelumnya.

b. Persyaratan terakhir adalah dapat diterapkan dalam industri (industrial applicability). Suatu penemuan agar layak diberi Paten harus dapat diterapkan untuk tujuan-tujuan praktis, artinya penemuan tidak dapat bersifat teoritis semata- mata, melainkan harus dapat dilaksanakan dalam praktek.

Persyaratan substantif sebagaimana dikemukakan diatas yaitu yang mempersyaratkan suatu invensi dapat dimohonkan Paten apabila memenuhi syarat yaitu : Harus Baru, Mengandung Langkah Inventif, serta dapat diterapkan dalam dunia Industri, hal tersebut dapat diketahui melalui ketentuan pasal 2 hingga pasal 5 Undang-Undang Paten. Dokumen paten memberikan informasi teknik yang terbaru, oleh sebab itu penemu selalu mencoba untuk mendaftarkan penemuannya sesegera mungkin pada kantor paten. Informasi yang ada dalam dokumen paten umumnya mengandung dua tipe informasi yaitu information bibliografi dan informasi teknik. Informasi bibliografi secara umum meliputi ; tanggal pendaftaran aplikasi dokumen paten, nama inventor, pemilik, klasifikasi paten (IPC), judul penemuan, abstrak diskripsi penemuan termasuk gambar atau formula kimia jika ada dan lain-lain. Sedangkan informasi teknik dalam dokumen paten meliputi diskripsi singkat the state of the art dari teknologi yang diketahui oleh inventor.

Suatu invensi untuk bisa mendapatkan paten, paling tidak harus memenuhi beberapa syarat subtantif sebagaimana diatur dalam Pasal 2 ayat (1) UU. No. 13 tahun 2016 yaitu; invensi tersebut harus mengandung unsur kebaruan (novelty), bisa diterapkan dalam perindustrian (industrial aplicability), mempunyai nilai langkah inventif (inventive step), dan juga 
memenuhi syaratsayarat formil yang diatur dalam Pasal 24 UU. No. 13 Tahun 2016 dan Pasal 4 dan 5 PP. No. 34 Tahun 1991 Tentang Tata Cara Permintaan Paten.

Syarat kebaruan yang dianut Indonesia, sebagaiman diatur dalam Pasal 3 ayat (2) UU. No. 13 Tahun 2016 menyatakan bahwa teknologi dianggap baru apabila teknologi tersebut belum pernah diumumkan di Indonesia atau di luar negeri dalam suatu tulisan, uraian lisan, atau melalui peragaan. Sistem kebaruan yang dianut dalam Pasal 3 ayat (2) Undang-Undang No. 13 Tahun 2016 adalah Sistem kebaruan yang luas (world wide novelty).

Syarat kebaruan luas (world wide novelty) yang dianut Indonesia syarat kebaruan luas yang relative yaitu suatu penemuan tidak dianggap telah diumumkan apabila dalam jangka waktu paling lama enam bulan sebelum tanggal penerimaan:

a. invensi tersebut telah dipertunjukkan dalam suatu pameran internasional di Indonesia atau di luar negeri yang resmi atau diakui sebagai resmi atau dalam suatu pameran nasional Indonesia yang resmi atau diakui sebagai resmi.

b. invensi tersebut telah digunakan di Indonesia oleh penemunya dalam rangka percobaan dengan tujuan penelitian dan pengembangan. Invensi juga dianggap telah diumumkan apabila dalam jangka waktu 12 bulan sebelum penerimaan ternyata ada pihak lain yang mengumumkan dengan cara melanggar kewajiban untuk menjaga kerahasiaan invensi tersebut.

Pemeriksaan untuk membuktikan apakah suatu invensi tersebut merupakan langkah inventif atau bukan, merupakan suatu hal yang sulit di dalam praktik. Hal tersebut dikarenakan pemeriksaan suatu invensi dibuat atas dasar apa yang dikenal umum dalam bidang kreasi tertentu, serta apakah menurut anggapan sudah dikenal oleh para ahli di bidang invensi tersebut. Pasal 2 ayat (2) UU. No. 13 Tahun 2016 menyatakan bahwa suatu invensi mengandung langkah inventif apabila invensi tersebut dari seseorang yang mempunyai keahlian biasa dalam bidang teknik yang bersangkutan merupakan hal yang tidak dapat diduga sebelumnya (non-obviousness).

Penilaian bahwa suatu invensi merupakan hal yang tidak dapat diduga sebelumnya harus dilakukan dengan memperhatikan keahlian yang ada pada saat permohonan diajukan atau yang telah ada pada saat diajukan permohonan pertama dalam hal permohonan diajukan dengan hak prioritas. Hak prioritas adalah hak pemohon untuk mengajukan permohonan yang berasal dari negara yang tergabung dalam Paris Convention for Protection of Industrial Property atau Agreement Establishing the World Trade Organization 
untuk memperoleh pengakuan bahwa tanggal penerimaan di negara asal merupakan tanggal prioritas di negara tujuan yang juga anggota salah satu dari keputusan langkah inventif diambil dengan mengetahui secara benar tingkatan teknik di bidang invensi pada saat permohonan diajukan, sambil mengamati bagaimana orang yang ahli dibidangnya (orang yang mempunyai pengetahuan biasa pada bidang invensi tersebut), melihat apakah orang yang ahli di bidang invensi tersebut bisa atau tidak membuktikan secara logis bahwa invensi yang diklaim berdasarkan invensi pembanding.

Sebagai kesimpulan, apabila orang yang ahli di bidang invensi yang diklaim (orang yang mempunyai pengetahuan biasa pada bidang invensi tersebut) dapat membuktikan secara logis maka, langkah inventif pada invensi yang diklaim tersebut akan ditolak, dan sebaliknya apabila ahli di bidang invensi yang diklaim tersebut tidak bisa membuktikan secara logis maka, langkah inventif pada invensi yang diklaim tersebut diterima.(Imam Sjahputra, 2007)

3) Tolak ukur invensi yang tidak dapat diberikan paten menurut UU No. 13 Tahun 2016 tentang Paten

Indonesia juga sudah mengeluarkan No. 13 Tahun 2016 tentang Paten, tetapi aturan mengenai invensi yang tidak dapat diberi hak paten tidak mengalami perubahan jika dibandingkan dengan undang-undang sebelumnya yaitu UU. No. 14 tahun 2001. Mengenai penemuan yang dapat diberikan paten menurut Pasal 2 UU No. 14 Tahun 2001 menegaskan:

1. Paten diberikan untuk invensi yang baru dan mengandung langkah inventif serta dapat diterapkan kedalam industri;

2. Suatu invensi mengandung langkah inventif jika invensi tersebut bagi seseorang yang mempunyai keahlian tertentu di bidang teknik merupakan hal yang tidak dapatdidugasebelumnya;

3. Penilaian bahwa suatu invensi merupakan hal yang tidak dapat diduga sebelumnya harus dilakukan dengan memperhatikan keahlian yang ada pada saat permohonan itu diajukan dengan hak prioritas.

Paten tidak diberikan untuk invensitentang:

a. Proses atau produk yang pengumuman dan penggunaan atau pelaksanaannya bertentangan dengan peraturan perundang-undangan yang berlaku, moralitas agama, ketertiban umum atau kesusilaan.

b. Metode pemeriksaan, perawatan, pengobatan dan pembedahan yang diterapkan terhadap manusia atau hewan;

c. Teoridanmetode dibidang ilmu pengetahuan dan matematika;

d. Semua makhluk hidup, kecuali jasad renik, proses biologis yang esensial untuk memproduksi tanaman atau hewan. 
Paten sebagaimana dimaksud di atas diberikan untuk jangka waktu 20 (dua puluh) tahun terhitung sejak tanggal penerimaan dan jangka waktu tersebut tidak diperpanjang. Adapun untuk untuk paten sederhana diberikan jangka waktu 10 (sepuluh) tahun terhitung sejak tanggal penerimaan dan jangka waktu tersebut juga dapat diperpanjang.

\section{4) Cara Pembatalan Paten}

Kepemilikan terhadap paten sebuah hasil karya wajib melalui proses panjang. Bahkan, ancaman pencabutan paten dapat diberlakukan ketika tidak membayar biaya tahunan.Namun UU Paten teranyar pun mengatur penghapusan hak paten terhadap hasil karya.Setidaknya terdapat beberapa hal yang mesti menjadi perhatian bagi kalangan pemegang hak paten. Sebagaimana tertuang dalam Pasal 130 UU Paten, setidaknya paten dapat dihapus sebagian atau seluruhnya. Penyebabnya antara lain, pertama, permohonan penghapusan dari pemegang paten dikabulkan oleh menteri. Kedua, putusan pengadilan yang menghapuskan paten dimaksud telah memiliki kekuatan hukum tetap. Ketiga, putusan penghapusan paten yang diterbitkan oleh Komisi Banding Paten. Keempat, pemegang paten tidak memenuhi kewajiban membayar biaya tahunan.

Alasan penghapusan paten yang diajukan ke pihak kementerian dilakukan berdasarkan permohonan tertulis.Pihak pengaju merupakan pemegang hak paten terhadap seluruh atau sebagian klaim kepada pihak kementerian.Nah, bila permohonan penghapusan sebagian klaim, maka disesuaikan dengan tidak memperluas ruang lingkup klaim. Terhadap penghapusan paten tak dapat dilakukan sepanjang penerima lisensi tidak memberikan persetujuan tertulis yang dilampirkan pada permohonan penghapusan paten.

Keputusan terhadap penghapusan paten disampaikan oleh menteri secara tertulis kepada pemegang paten, pemegang lisensi atau kuasanya. Hasil keputusan menteri terhadap permohonan penghapusan paten dicatat dan diumumkan melalui media elektronik maupun non elektronik. Penghapusan paten resmi berlaku sejak tanggal ditetapkannya keputusan menteri tersebut. Penghapusan paten merujuk putusan pengadilan dilakukan bila tidak mengikuti aturan antara lain invensi tidak mencakup kreasi estetika, skema, aturan dan metode untuk melakukan kegiatanyang melibatkan kegiatan mental, permainan dan bisnis. Kemudian invensi tidak mencakup aturan dan metode yang hanya berisi program komputer, temuan berupa penggunaan baru untuk produk yang sudah ada. Kemudian, proses produk, penggunaan atau pelaksanaannya bertentangan dengan peraturan perundangan, agama, dan ketertiban umum. 
Kemudian, paten dimaksud ternyata sama dengan invensi lain yang sudah diberikan paten terlebih dahulu. Tak hanya itu, pemberian lisensi wajib ternyata tidak mampu mencegah berlangsungnya pelaksanaan paten dalam bentuk dan cara yang merugikan kepentingan masyarakat dalam waktu dua tahun. Tak kalah penting, ternyata pemegang paten melanggar ketentuan dengan tidak membuat produk dan menggunakan prosesnya di Indonesia.Bahkan tidak mentransfer teknologi penyerapan investasi serta penyediaan lapangan pekerjaan.

UU Paten pun menjelaskan penghapusan paten dilakukan bila pemegang paten tidak memenuhi kewajibannya membayar biaya tahunan dalam jangka waktu yang sudah ditentukan.Menteri, wajib memberitahukan pihak pemegang paten dalam kurun waktu 30 hari sebelum paten dinyatakan dihapus.Terhadap paten yang dinyatakan dihapus, menteri terkait wajib memberitahukan secara tertulis melalui eketronik maupun non elektronik kepada pemegang paten, penerima lisensi atau kuasanya.Selain itu penghapusan paten tertentu wajib dicatat dan diumumkan. Pemegang paten atau penerima lisensi yang dinyatakan hapus tidak dikenakan kewajiban membayar iuran tahunan.Selain itu menghilangkan pula segala akibat hukum yang berkaitan dengan paten."Paten yang telah dihapus tidak dapat dihidupkan kembali, kecuali berdasarkan putusan pengadilan" tutup Pasal 141 UU Paten.

\section{PENUTUP}

Paten diberikan untuk invensi yang baru, mengandung langkah inventif, dan dapat diterapkan dalam industri. Sementara paten sederhana diberikan untuk setiap invensi baru, pengembangan dari produk atau proses yang telah ada, dan dapat diterapkan dalam industri. Paten sederhana diberikan untuk invensi yang berupa produk yang bukan sekadar berbeda ciri teknisnya, tetapi harus memiliki fungsi/kegunaan yang lebih praktis daripada invensi sebelumnya yang disebabkan bentuk, konfigurasi, konstruksi, atau komponennya yang mencakup alat, barang, mesin, komposisi, formula, senyawa, atau sistem. Paten sederhana juga diberikan untuk invensi yang berupa proses atau metode yang baru. Maksimum perlindungan paten sederhana lebih pendek daripada maksimum perlindungan paten. Perlindungan untuk paten sederhana sesuai dengan Pasal 23 ayat (1) UU Paten adalah selama 10 tahun terhitung sejak tanggal penerimaan, sedangkan paten sesuai Pasal 22 ayat (1) UU Paten diberikan untuk jangka waktu 20 tahun sejak tanggal penerimaan. Klaim paten sederhana dibatasi dengan satu klaim mandiri, sedangkan paten jumlah klaimnya tidak dibatasi. Progres teknologi dalam paten sederhana lebih simpel daripada progres teknologi dalam paten. 


\section{DAFTAR PUSTAKA}

\section{A. Buku-buku}

Rachmadi Usman. 2003. Hukum Hak atas Kekayaan Intelektual Perlindungan dan Dimensi Hukumnya di Indonesia. Alumni, Bandung.

Oentoeng Soerapati. 1999. Hukum Kekayaan Intelektual dan Alih Teknologi. Satya Wacana, Salatiga

Shidarta. 2009. Misnomer dalam Nomenklatur dan Penalaran Positivisme Hukum. Yayasan Obor Indonesia, Jakarta.

John Locke. 1997. Summa Theologiae dalam Sonny Keraf, Hukum Kodrat dan Teori Hak Milik Pribadi. Kanisius, Yogyakarta.

Marshall Leaffer. 2007. Understanding Copyright Law. Oxford Legal Publisher, Kanada.

Mahadi. 1981. Hak Milik dalam sistem Hukum Perdata Nasional. BPHN, Jakarta.

Titik Triwulan Tutik. 2008. Hukum Perdata dalam Sistem Hukum Nasional. Kencana, Jakarta.

\section{A. Peraturan Perundang-Undangan}

Undang-Undang No. 14 tahun 2001 tentang Paten

Undang-Undang No. 13 tahun 2016 tentang Paten

\section{B. Sumber Lain}

Monika Suhayati., Perlindungan Hukum Terhadap Hak Ekonomi Pemilik Hak Terkait Dalam Undang-Undang Nomor : 28 Tahun 2014 Tentang Hak Cipta. Jurnal Ilmiah Hukum Negara Hukum (Membangun Hukum Untuk Keadilan dan Kesejahteraan) Volume 5 Nomor : 2 Nopember 2014. Pusat Kajian, Pengolahan Data dan Informasi (P3DI) Sekretariat Jenderal Dewan Perwakilan Rakyat Republik Indonesia. 


\section{PEDOMAN PENULISAN \\ JURNAL PRANATA HUKUM}

1. Naskah bersifat orisinil, baik berupa hasil riset atau tinjauan atas suatu permasalahan hukum yang berkembang di masyarakat (artikel lepas), dimungkinkan juga tulisan lain yang dipandang memberikan kontribusi bagi pengembangan ilmu hukum.

2. Penulisan terdiri atas beberapa bab penulisan hasil penelitian terdiri dari $3 \mathrm{BAB}$, yaitu ;

BAB I. PENDAHULUAN (Latar Belakang dan Rumusan Masalah) BAB II. PEMBAHASAN (Kerangka Teori dan Analisis), dan BAB III. PENUTUP (Kesimpulan dan Saran).

3. Tulisan menggunakan bahasa indonesia maupun bahasa inggris yang memenuhi kaidah bahasa yang baik dan benar,tulisan menggunakan bahasa indonesia disertai abstrak dalam bahasa inggris (200 kata) dan Kata kunci, ketentuan ini berlaku sebaliknya.

4. Setiap kutipan harus menyebutkan sumbernya dengan format footnote. Sumber kutipan harus memuat nama pengarang, tahun penerbitan, judul buku, nama penerbit, kota penerbit, dan halaman. Contoh : Bagir Manan. 1994. Hubungan Antara Pemerintah Pusat dan Daerah Menurut UUD 1945. Pustaka Sinar Harapan. Jakarta. 1994, hlm. 19. Untuk artikel dari internet dengan susunan: nama penulis, judul tulisan digaris bawah, alamat website, waktu download/unduh.

5. Naskah harus disertai dengan daftar pustaka atau referensi ,terutama yang digunakan sebagai bahan acuan langsung. Daftar pustaka dan referensi bersifat alfabetis dengan format; nama pengarang, judul buku, nama penerbit, kota terbit, dan tahun penerbitan. Contoh: Bagir Manan. 1994. Hubungan Antara Pemerintah Pusat dan Daerah Menurut UUD 1945. Pustaka Sinar Harapan. Jakarta.

6. Panjang tulisan antara 15-25 halaman, font cambria dengan 1,15 spasi. Dalam hal hal tertentu berlaku pengecualian panjang tulisan.

7. Naskah disertai nama lengkap penulis, alamat e-mail dan lembaga tempat berafiliasi saat ini, dan hal lain yang dianggap penting. 
Jurnal PRANATA HUKUM dimaksudkan sebagai media komunikasi, edukasi, dan informasi ilmiah bidang ilmu hukum khususnya, dan ilmu sosial pada umumnya. Sajian dan kemasan diupayakan komunikatif melalui bahasa ilmiah.

Redaksi mengundang semua elemen masyarakat baik civitas akademika, praktisi, lembaga masyarakat, maupun perorangan yang berminat terhadap bidang hukum untuk berpartisipasi mengembangkan gagasan, wawasan, dan pengetahuan melalui tulisan untuk dimuat dalam jurnal ini.

Melalui PRANATA HUKUM diharapkan terjadi proses pembangunan dan pengembangan bidang hukum sebagai bagian penting dari rangkaian panjang proses memajukan masyarakat bangsa.
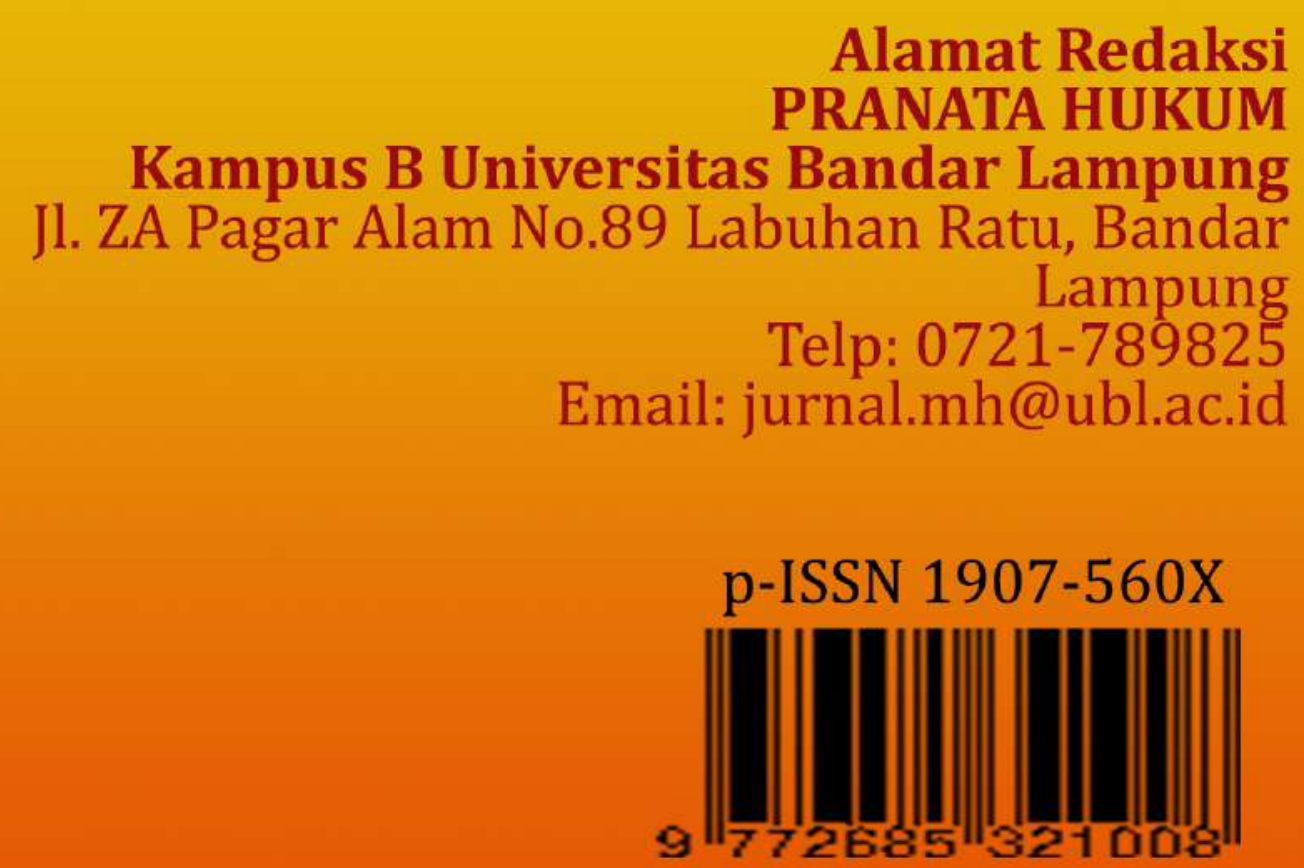